\title{
Limnological survey in eight high mountain lakes located in Lago Maggiore watershed (Switzerland)
}

\author{
Alberto BARBIERI*, Mauro VERONESI, Marco SIMONA, Stefano MALUSARDI and Viera STRAŠKRABOVÁ1) \\ Laboratorio Studi Ambientali, SPAA - DT, 6900 Lugano-Paradiso, Canton Ticino, Switzerland \\ ${ }^{1)}$ Hydrobiological Institute, Czech Academy of Sciences and University of South Bohemia, Faculty of Biology, Na sádkách 7, 37005 \\ Č. Budějovice, Czech Republic \\ *e-mail corresponding author: alberto.barbieri@ti.ch
}

\begin{abstract}
Eight high mountain lakes located above $2000 \mathrm{~m}$ a.s.l. in the watershed of Lago Maggiore, with alkalinity between 10 and 100 $\mu e q l^{-1}$, were studied during summer 1997. The survey revealed that some of the lakes had a saline density gradient which might hinder the mixing of water and restrict the oxygenation in hypolimnion. Following acidification, aluminium was present in some lakes in the form of $\mathrm{Al}(\mathrm{OH})_{2}{ }^{+}$, with $\mathrm{pH}$ around 5.9, and as $\mathrm{Al}(\mathrm{OH})_{4}{ }^{-}$, with $\mathrm{pH}$ around 6.6. The negative correlation observed between $\mathrm{pH}$ and nitrate concentrations seems to be linked to vegetal activity. In fact, acidity in soil and water, combined with the presence of aluminium, can partially inhibit the metabolism of plants and algae, and reduce the assimilation of $\mathrm{NO}_{3}^{-}$. Major biological differences emerged among the lakes, both at the level of plankton composition and biomass, and in seasonal dynamics. Dinophyceans and chlorophyceans predominated quantitatively in the lakes with low $\mathrm{pH}$ and alkalinity values, whereas diatoms were present in the lakes with higher values of these parameters. The phytoplankton biodiversity index showed a considerable variation from lake to lake. Higher alkalinity and salinity was not coupled to a higher biocenosis diversity and one or two species tend to dominate the others.
\end{abstract}

Key words: alpine lakes, water chemistry, acidification, phytoplankton diversity, seasonal variations

\section{INTRODUCTION}

During the past 20 years, the Laboratorio Studi Ambientali (LSA) has studied the limnology of high altitude Alpine lakes in the Ticino Canton. Many of these studies have been carried out in collaboration with the C.N.R. Istituto Italiano di Idrobiologia, which works in the mountain lakes of the Ossola Valley, bordering on the Canton Ticino (Boggero et al. 1996, 1998).

The studies on lake water chemistry have concentrated particularly on problems of acidification; due to the geological characteristics of the area, many lakes are poorly buffered (Boggero et al. 1996, 1998). On the other hand, the atmospheric depositions have a considerable degree of acidity (Boggero et al. 1996, 1998); they have been studied through a network of stations distributed over the whole territory of the Canton, which also considers high mountain sites (Robiei, Naret, Piotta, LSA internal report).

Lake chemistry studies were divided into six surveys, performed at roughly three-year intervals in a set of 21 lakes; larger groups (50 lakes) were also studied occasionally. A summary of the results is reported by Boggero et al. (1996).

During summer 1997 we performed a study in 8 lakes located above the treeline, with alkalinity between 5 and $100 \mu \mathrm{eq} 1^{-1}$. On the basis of three monthly samplings during the summer season, we tried to characterise the water column of the lakes, using not only the series of chemical parameters and physicochemical meas- urements, but also the data on biological parameters: phytoplankton and crustacean zooplankton.

This paper presents a combined evaluation of both abiotic and biotic parameters and their interactions, based on methodological approaches and conceptual ideas of the European project MOLAR (Mountain Lakes Research, ENV4-CT95-0007, of the EU Environment and Climate Programme). Main aim of this project is to study the reaction of remote mountain lakes ecosystems to acid deposition (sulphur plus nitrogen) and to measure and model their temporal responses to climate variability (Patrick et al. 1998). The response of plankton biomass and structure to changing water chemistry, especially in low-alkalinity mountain lakes, is expected (The MOLAR Water Chemistry Group 1999, this issue; Straškrabová et al. 1999, this issue), and we try to test it in the series of lakes, differing mainly in $\mathrm{pH}$, alkalinity and conductivity.

\section{METHODS}

\subsection{Studied area and lakes}

The study area is in the valley of the Maggia River, a tributary to Lake Maggiore, in the Central Alps (Fig. 1). In this watershed, we selected 8 alpine lakes for our study. The geographic and morphometric characteristics of lakes and their catchments are given in table 1 . The lithology of lakes is determined by their location in the Pennine blanket, bordering with the Gotthard Massifs and Helvetic and Ultrahelvetic sediments (Cotti et al. 1990). Detailed maps of lithological composition and 


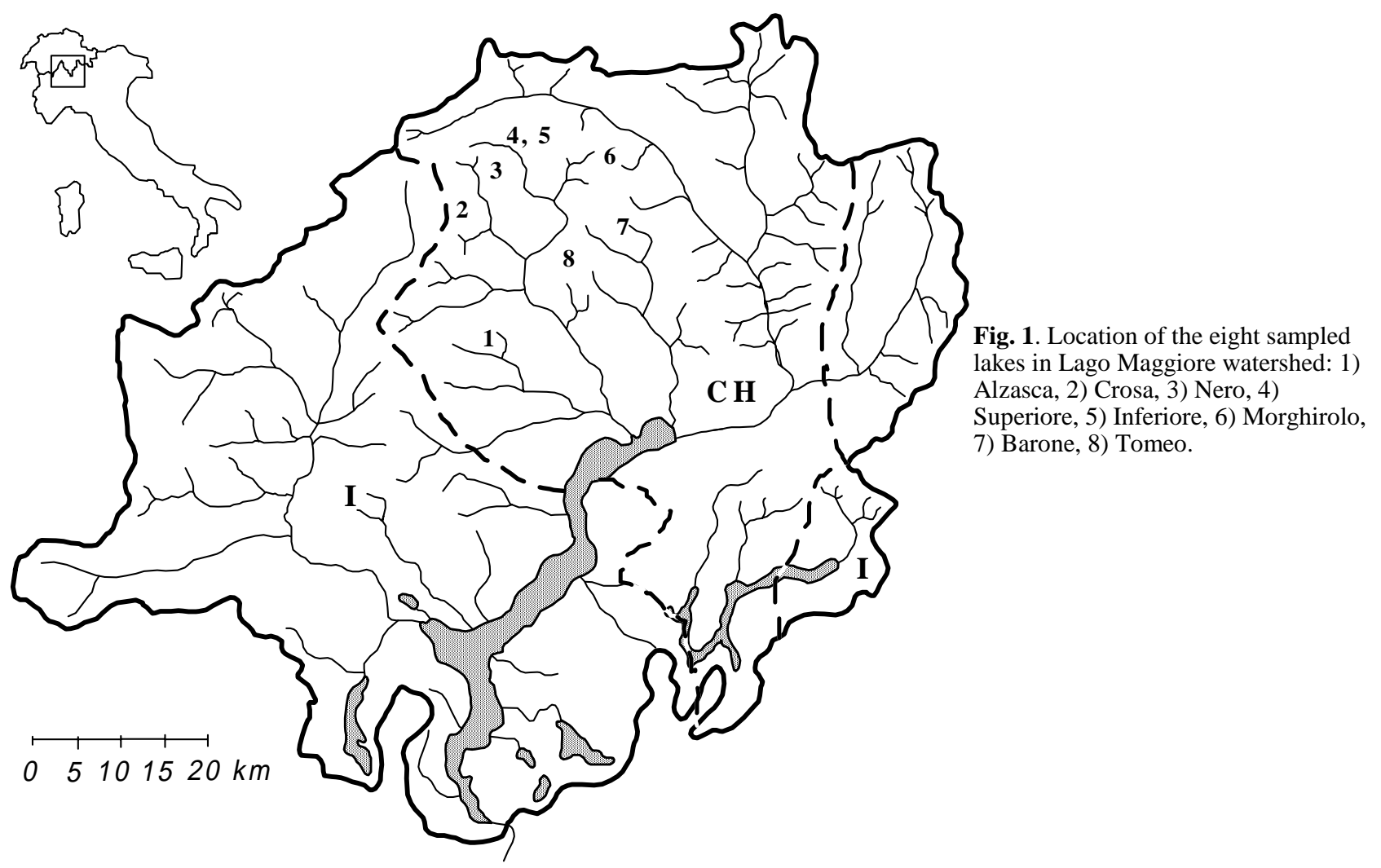

Tab. 1. Main geomorphological and hydrological characteristics of the sampled lakes. *Estimated from $2.5 \mathrm{~m} \mathrm{y}^{-1}$ precipitation.

\begin{tabular}{|c|c|c|c|c|c|c|c|c|}
\hline \multirow[t]{2}{*}{ Lakes } & \multicolumn{2}{|c|}{ Coordinates } & \multirow{2}{*}{$\begin{array}{l}\text { Altitude } \\
\text { [m a.s.1.] }\end{array}$} & \multirow{2}{*}{$\begin{array}{c}\text { Max. depth } \\
{[\mathrm{m}]}\end{array}$} & \multirow{2}{*}{$\begin{array}{c}\text { Lake area } \\
{\left[\mathrm{km}^{2}\right]}\end{array}$} & \multirow{2}{*}{$\begin{array}{c}\text { Drainage basin } \\
{\left[\mathrm{km}^{2}\right]}\end{array}$} & \multirow{2}{*}{$\begin{array}{l}\text { Lake volume } \\
\qquad\left[\mathrm{m}^{3}\right] \times 10^{6}\end{array}$} & \multirow{2}{*}{$\begin{array}{l}\tau_{\mathrm{w}} * \\
{[\mathrm{~d}]}\end{array}$} \\
\hline & Long. E & Lat. $\mathrm{N}$ & & & & & & \\
\hline Tomeo & $08^{\circ} 41^{\prime} 27^{\prime \prime}$ & $46^{\circ} 21^{\prime} 51^{\prime \prime}$ & 1692 & 38 & 0.046 & 2.89 & 0.6 & 30 \\
\hline Barone & $08^{\circ} 45^{\prime} 06^{\prime \prime}$ & $46^{\circ} 24^{\prime} 18^{\prime \prime}$ & 2391 & 56 & 0.060 & 0.50 & 1.1 & 321 \\
\hline Nero & $08^{\circ} 32^{\prime} 30^{\prime \prime}$ & $46^{\circ} 26^{\prime} 50^{\prime \prime}$ & 2387 & 68 & 0.120 & 0.74 & 2.7 & 533 \\
\hline Crosa & $08^{\circ} 29^{\prime} 00^{\prime \prime}$ & $46^{\circ} 22^{\prime} 21^{\prime \prime}$ & 2153 & 70 & 0.170 & 1.92 & 4.0 & 304 \\
\hline Laghetto Inferiore & $08^{\circ} 35^{\prime} 38^{\prime \prime}$ & $46^{\circ} 28^{\prime} 37^{\prime \prime}$ & 2074 & 33 & 0.048 & 1.76 & 0.5 & 41 \\
\hline
\end{tabular}

vegetation cover in the catchments are given by Boggero et al. (1996), basic data relevant to the 8 lakes considered in the paper, are shown in table 2. Catchments are made up predominantly of bedrock (73-90\%) with a lower area occupied by alpine meadows (2-7\%) and water (i.e., lakes: $2-17 \%$ ). Only the catchment of Lake Alzasca has a higher proportion of meadows (42\%), and a smaller percentage of bedrock $(38 \%)$.

Fish are present in all the lakes (stocked by brown trout, Salmo trutta). Meadows in catchments are used for pasture.

\subsection{Lake sampling}

In August, September and October, samples were taken at the point of maximum depth, using a small boat. Measurements of temperature, $\mathrm{pH}$, dissolved oxygen and conductivity profile (at $0.5 \mathrm{~m}$ intervals) were performed in the field, with an Idronaut multiparametric probe (model Ocean Seven 316). Transparency was measured by Secchi disc. Samples for chemical analysis were taken by a 5 liter sampler from the whole water column at $5 \mathrm{~m}$ intervals. At these depths the dissolved oxygen concentration was also measured, using Winkler's method (Winkler 1888).

\subsection{Methods for chemical analyses and quality control}

The chemical variables examined are listed in table 4. The respective analytical methods are described in Barbieri \& Mosello (1999), with the exception of iron, manganese and aluminium, whose detection procedures are reported in table 3 . This latter table also specifies, in addition to the measurement range, the LOQ (Lower quantification limit following the IUPAC indication) (A.A.V.V. 1980; Analytical Methods Committee 1987). 
Tab. 2. Lithological and vegetation percentage cover of the different catchment areas (from Boggero et al. 1996).

\begin{tabular}{lccccccc}
\hline Lake & \multicolumn{9}{c}{ Catchment cover [\%] } & Lithology \\
\cline { 2 - 6 } & Water & Pasture & Bedrocks & Conifers & Shrubs & Glacier & Rocks \\
\hline Tomeo & 2 & 9 & 86 & 2 & 1 & & acidic \\
Barone & 13 & 4 & 83 & & & & acidic+femic \\
Crosa & 9 & 2 & 90 & & & & acidic \\
Laghetto Superiore & 7 & 6 & 88 & & & 5 & acidic+femic \\
Morghirolo & 7 & 7 & 81 & & & & acidic \\
Laghetto Inferiore & 7 & 7 & 84 & & & acidic+femic \\
Nero & 17 & 9 & 73 & & 6 & & acidic \\
Alzasca & 9 & 42 & 38 & 5 & 6 & & acidic \\
\hline
\end{tabular}

Tab. 3. Methods of chemical analysis, working ranges and limits of quantification (L.O.Q.) of iron, manganese and aluminium.

\begin{tabular}{|c|c|c|c|c|c|c|}
\hline Parameter & Method & References & Unit & Min. & Max. & L.O.Q. \\
\hline Iron & Colorimetry continuos flow & $\begin{array}{c}\text { Operation manual autoanalyser } \\
\text { Bran+Luebbe TRAACS }\end{array}$ & $\mu g l^{-1}$ & 10 & 100 & 11.5 \\
\hline Manganese & Colorimetry continuos flow & $\begin{array}{c}\text { Operation manual autoanalyser } \\
\text { Bran+Luebbe TRAACS }\end{array}$ & $\mu g 1^{-1}$ & 15 & 150 & 17.2 \\
\hline Aluminium & Colorimetry continuos flow & $\begin{array}{c}\text { Operation manual autoanalyser } \\
\text { Bran+Luebbe TRAACS }\end{array}$ & $\mu \mathrm{g} \mathrm{l}^{-1}$ & 20 & 200 & 0.18 \\
\hline
\end{tabular}

Tab. 4. Mean values and standard deviations of chemical variables for each lake. The average is calculated over the three series of data. Transparency values as Secchi disk depth are also reported.

\begin{tabular}{|c|c|c|c|c|c|c|c|c|c|}
\hline Parameters & Unit & Tomeo & Barone & Crosa & Superiore & Morghirolo & Inferiore & Nero & Alzasca \\
\hline Temperature & {$\left[{ }^{\circ} \mathrm{C}\right]$} & $7.7 \pm 2.7$ & $5.7 \pm 2.5$ & $7.2 \pm 3.1$ & $8.2 \pm 2.8$ & $7.4 \pm 3.0$ & $6.8 \pm 3.0$ & $5.7 \pm 2.5$ & $7.5 \pm 4.5$ \\
\hline Transparency & {$[\mathrm{m}]$} & $30.0 \pm 4.0$ & $16.2 \pm 5.0$ & $18.7 \pm 2.5$ & $11.7 \pm 2.5$ & $8.5 \pm 2.6$ & $12.9 \pm 0.2$ & $10.0 \pm 1.0$ & $9.3 \pm 0.3$ \\
\hline Dissolved $\mathrm{O}_{2}$ & {$\left[\mathrm{mg} \mathrm{l}^{-1}\right]$} & $9.59 \pm 0.67$ & $8.36 \pm 1.33$ & $9.13 \pm 1.02$ & $9.60 \pm 1.04$ & $9.41 \pm 1.19$ & $9.98 \pm 0.94$ & $8.92 \pm 2.04$ & $8.52 \pm 2.92$ \\
\hline Conductivity $20^{\circ} \mathrm{C}$ & {$\left[\mu \mathrm{S} \mathrm{cm}^{-1}\right]$} & $9.5 \pm 0.5$ & $9.8 \pm 0.6$ & $8.1 \pm 0.7$ & $8.3 \pm 0.4$ & $10.5 \pm 0.4$ & $11.4 \pm 2.6$ & $16.7 \pm 1.5$ & $17.8 \pm 2.1$ \\
\hline $\mathrm{pH}$ & {$[-]$} & $5.9 \pm 0.1$ & $6.0 \pm 0.2$ & $6.3 \pm 0.1$ & $6.6 \pm 0.2$ & $6.7 \pm 0.3$ & $6.7 \pm 0.2$ & $7.0 \pm 0.5$ & $7.0 \pm 0.7$ \\
\hline Alkalinity & {$\left[\mu\right.$ eq $\left.1^{-1}\right]$} & $8.4 \pm 4.9$ & $11.9 \pm 3.9$ & $22.1 \pm 5.5$ & $27.9 \pm 4.8$ & $36.4 \pm 5.6$ & $41.7 \pm 16.1$ & $76.9 \pm 7.7$ & $93.0 \pm 14.1$ \\
\hline Sulphate & {$\left[\mu\right.$ eq $\left.1^{-1}\right]$} & $40.3 \pm 2.0$ & $43.1 \pm 1.8$ & $28.5 \pm 1.3$ & $33.5 \pm 2.0$ & $46.2 \pm 2.0$ & $43.9 \pm 9.2$ & $67.9 \pm 5.6$ & $58.3 \pm 4.7$ \\
\hline Chloride & {$\left[\mu \mathrm{eq} 1^{-1}\right]$} & $3.5 \pm 0.6$ & $3.1 \pm 0.3$ & $2.7 \pm 0.3$ & $2.0 \pm 0.2$ & $2.0 \pm 0.3$ & $2.3 \pm 0.5$ & $2.4 \pm 0.3$ & $4.5 \pm 0.4$ \\
\hline Calcium & {$\left[\mu\right.$ eq $\left.1^{-1}\right]$} & $53.0 \pm 6.7$ & $63.0 \pm 4.7$ & $57.9 \pm 5.8$ & $56.7 \pm 5.4$ & $67.6 \pm 5.5$ & $75.6 \pm 19.2$ & $124.7 \pm 11.7$ & $123.2 \pm 12.6$ \\
\hline Magnesium & {$\left[\mu \mathrm{eq} \mathrm{l}^{-1}\right]$} & $7.0 \pm 0.9$ & $7.7 \pm 1.2$ & $7.0 \pm 1.5$ & $8.5 \pm 0.7$ & $13.7 \pm 1.7$ & $10.8 \pm 1.8$ & $13.9 \pm 1.4$ & $20.1 \pm 2.8$ \\
\hline Sodium & {$\left[\mu \mathrm{eq} 1^{-1}\right]$} & $12.9 \pm 1.4$ & $9.6 \pm 0.9$ & $8.9 \pm 2.2$ & $8.8 \pm 0.4$ & $9.7 \pm 0.9$ & $14.1 \pm 4.2$ & $13.7 \pm 1.8$ & $19.8 \pm 2.8$ \\
\hline Potassium & {$\left[\mu\right.$ eq $\left.1^{-1}\right]$} & $4.4 \pm 0.4$ & $5.2 \pm 0.3$ & $4.6 \pm 1.1$ & $8.2 \pm 0.3$ & $9.8 \pm 0.7$ & $12.5 \pm 2.9$ & $12.6 \pm 1.3$ & $14.1 \pm 2.4$ \\
\hline Ammonium & {$\left[\mu \mathrm{eq} \mathrm{l}^{-1}\right]$} & $0.5 \pm 0.4$ & $0.4 \pm 0.5$ & $0.6 \pm 0.6$ & $0.8 \pm 1.0$ & $1.5 \pm 1.6$ & $0.9 \pm 0.8$ & $0.5 \pm 0.5$ & $1.7 \pm 1.6$ \\
\hline Nitrite & {$\left[\mu\right.$ eq $\left.1^{-1}\right]$} & $0.08 \pm 0.07$ & $0.12 \pm 0.07$ & $0.11 \pm 0.06$ & $0.10 \pm 0.04$ & $0.09 \pm 0.04$ & $0.10 \pm 0.04$ & $0.09 \pm 0.04$ & $0.10 \pm 0.05$ \\
\hline Nitrate & {$\left[\mu \mathrm{eq} 1^{-1}\right]$} & $25.9 \pm 1.0$ & $21.5 \pm 0.7$ & $19.4 \pm 1.2$ & $13.4 \pm 1.1$ & $10.3 \pm 1.8$ & $15.6 \pm 1.1$ & $11.2 \pm 1.9$ & $15.8 \pm 3.6$ \\
\hline$\Sigma$ Anions & {$\left[\mu \mathrm{eq} 1^{-1}\right]$} & $78.1 \pm 6.9$ & $79.6 \pm 5.4$ & $72.6 \pm 7.9$ & $76.8 \pm 5.5$ & $92.9 \pm 6.1$ & $103.5 \pm 26.1$ & $158.3 \pm 14.6$ & $171.7 \pm 20.6$ \\
\hline$\Sigma$ Cations & {$\left[\mu \mathrm{eq}{ }^{-1}\right]$} & $78.7 \pm 8.4$ & $85.8 \pm 6.5$ & $78.5 \pm 8.4$ & $82.8 \pm 6.2$ & $99.9 \pm 7.8$ & $113.4 \pm 27.7$ & $164.9 \pm 15.2$ & $178.7 \pm 20.4$ \\
\hline Reactive silica & {$\left[\mathrm{mg} \mathrm{l}^{-1}\right]$} & $0.9 \pm 0.1$ & $0.7 \pm 0.1$ & $0.8 \pm 0.1$ & $0.5 \pm 0.0$ & $0.7 \pm 0.1$ & $0.7 \pm 0.2$ & $0.9 \pm 0.2$ & $1.4 \pm 0.4$ \\
\hline Reactive iron & {$\left[\mu \mathrm{g} \mathrm{l}^{-1}\right]$} & $4 \pm 2$ & $5 \pm 3$ & $2 \pm 1$ & $5 \pm 3$ & $6 \pm 5$ & $8 \pm 7$ & $3 \pm 1$ & $4 \pm 3$ \\
\hline Total iron & {$\left[\mu \mathrm{g} \mathrm{l}^{-1}\right]$} & $10 \pm 9$ & $13 \pm 15$ & $5 \pm 5$ & $15 \pm 7$ & $17 \pm 22$ & $15 \pm 10$ & $6 \pm 6$ & $10 \pm 8$ \\
\hline Total manganese & {$\left[\mu \mathrm{g} \mathrm{l}^{-1}\right]$} & $5 \pm 2$ & $5 \pm 3$ & $4 \pm 4$ & $6 \pm 5$ & $4 \pm 2$ & $5 \pm 2$ & $5 \pm 3$ & $7 \pm 4$ \\
\hline Reactive aluminium & {$\left[\mu \mathrm{g} \mathrm{l}^{-1}\right]$} & $11 \pm 8$ & $1 \pm 1$ & $0 \pm 0$ & $4 \pm 2$ & $0 \pm 0$ & $3 \pm 2$ & $0 \pm 0$ & $0 \pm 0$ \\
\hline Total aluminium & {$\left[\mu \mathrm{g} \mathrm{l}^{-1}\right]$} & $15 \pm 8$ & $2 \pm 3$ & $0 \pm 1$ & $6 \pm 2$ & $1 \pm 3$ & $6 \pm 4$ & $0 \pm 1$ & $0 \pm 0$ \\
\hline
\end{tabular}

The LSA takes part regularly, with good results, in intercalibration exercises for analytical methods, on rainwater as well as surface water samples, in the framework of the EU programme AQUACON (Analytical Quality Control and Assessment Studies in the Mediterranean Basin, Mosello et al. 1996) and in the framework of ICP Assessment and Monitoring of acidification of Rivers and Lakes (Håvind 1998).

The results of the analyses relating to this study are validated on the basis of the ionic balance and by the comparison between measured conductivity and that calculated from the ionic concentrations multiplied by the respective conductivity equivalents, following the methods adopted by the MOLAR programme (NIVA 1996).

\subsection{Plankton sampling and elaboration}

Samples for phytoplankton analyses were taken at the same depths as the chemical ones. The aliquots collected $(50 \mathrm{ml})$ from all depths were mixed to make up 
the integrated sample representative of the whole water column. One lake, Laghetto Inferiore, was sampled in a different way, with a Schröder bottle, enabling us to take an integrated sample of the layers from 0 to $25 \mathrm{~m}$. Samples were immediately preserved with acetic Lugol and kept cool. Algal species were determined and counted using direct microscope and inverted microscope.

Crustacean zooplankton was collected by tows through the whole water column with nets of $10 \mathrm{~cm} \mathrm{di-}$ ameter and $41 \mu \mathrm{m}$ mesh size. Samples were preserved with acetic Lugol and investigated with a stereoscopic microscope.

\section{RESULTS}

\subsection{Lake chemistry}

The composition of lake waters is affected to a considerable extent by atmospheric loading, which is the main source of nitrate (40-70 meq $\left.\mathrm{m}^{-2} \mathrm{y}^{-1}\right)$ and sulphate (50-100 meq m $\mathrm{m}^{-2} \mathrm{y}^{-1}$ ) in lake water (Boggero et al. 1996). On the other hand, weathering phenomena neutralise the atmospheric acidity, which is present in the free form $\left(\mathrm{H}^{+}\right)$and/or arises as a product of ammonia oxidation. In spite of an important contribution of ammonia in the atmospheric deposition, the concentrations of ammonium ion in lakes were almost negligible. Table 4 shows the ranges of seasonal values of the physical and chemical parameters measured in samples taken along the water column in the 8 lakes. All measured values of reactive $\mathrm{Mn}$ and reactive $\mathrm{P}$ were below the detection limit (LOQ) and are not shown. Mean water transparency was between 9 and 19 m, except in Lake Tomeo (30 m).

During the three measurement campaigns, saline concentrations showed a marked vertical gradient (on average $+20 \%$ ) and a small seasonal increase (+5\%). Weathering had resulted in the formation of a low alkalinity reserve with values between $8 \mu$ eq $\mathrm{l}^{-1}$ (Tomeo) and $93 \mu \mathrm{eq} \mathrm{l}^{-1}$ (Alzasca). The $\mathrm{pH}$ values consequently ranged from 5.9 (Tomeo) to 7.0 (Alzasca and Nero). The other main anions had a fairly limited variation range: sulphate $\left(29-68 \mu\right.$ eq $\left.1^{-1}\right)$, nitrate $\left(10-26 \mu\right.$ eq $\left.1^{-1}\right)$ and chloride $\left(2.0-4.5 \mu \mathrm{eq} \mathrm{l}^{-1}\right)$. The main cations were calcium (53-125 $\mu \mathrm{eq}^{-1}$ ) and sodium (8.8-19.8 $\left.\mu \mathrm{eq} \mathrm{l}^{-1}\right)$, and to a lesser extent potassium (4.4-14.1 $\left.\mu \mathrm{eq} \mathrm{l}^{-1}\right)$ and magnesium $\left(7-20 \mu \mathrm{eq} 1^{-1}\right)$. Nitrite and ammonium were occasionally found, only at some depths, with values slightly above the LOQ; as a result, their mean concentration in the water column is extremely low. Reactive phosphorus was always below the LOQ at all depths, and reactive silica was measured in concentrations between 0.46 and $1.36 \mathrm{mg} \mathrm{SiO}_{2} \mathrm{l}^{-1}$. Values of iron, manganese and aluminium, both dissolved and total, were generally below the LOQ. However, dissolved and total aluminium was present along the whole water column in Tomeo (2-31 $\left.\mathrm{g} \mathrm{l}^{-1}\right)$, and in the superficial layers of Lakes Superiore and Inferiore (1-14 $\left.\mu \mathrm{g} \mathrm{l}^{-1}\right)$. Dissolved iron was observed only in Lake Barone (2-13 $\left.\mu \mathrm{g} \mathrm{l}^{-1}\right)$, while total iron was found only in the first sampling (beginning of August) in lakes Tomeo and Superiore (7$\left.33 \mu \mathrm{g} \mathrm{l}^{-1}\right)$, Barone and Morghirolo (10-79 $\mu \mathrm{g} \mathrm{l}^{-1}$ ), and Inferiore $\left(9-43 \mu \mathrm{g} \mathrm{l}^{-1}\right)$.

\subsection{Vertical profile}

The three samplings on the water column revealed a vertical density gradient, due in the first place to temperature, and then to the increase in saline concentration with increasing depth (Tab. 5). The mean surface temperature ranged from $10.8{ }^{\circ} \mathrm{C}$ (Nero) to $15.4{ }^{\circ} \mathrm{C}$ (Alzasca), while the values near the sediment were between $4.0{ }^{\circ} \mathrm{C}$ (Barone and Nero) and $5.8{ }^{\circ} \mathrm{C}$ (Tomeo). In surface waters the mean conductivity (corrected to $20{ }^{\circ} \mathrm{C}$ ) was between 8.0 and $10.6 \mu \mathrm{S} \mathrm{cm}^{-1}$, while the values for the bottom waters ranged from $9.0 \mu \mathrm{S} \mathrm{cm}^{-1}$ (Superiore) to $20.4 \mu \mathrm{S} \mathrm{cm}^{-1}$ (Alzasca).

The water density $(\rho)$ had been roughly calculated as the sum of the density due to temperature and that due to the saline concentration. For a greater clarity, a transformation of scale was performed by introducing the term of density anomaly, calculated as $(\rho-1)$. The density anomaly highlighted a marked difference between the surface values, which were within the range -343 and $-937 \mathrm{mg} 1^{-1}$, and the bottom values which were higher, ranging between -4 and $+50 \mathrm{mg}^{-1}$ (Tab. 5). Dissolved substances such as $\mathrm{Ca}^{2+}, \mathrm{SO}_{4}{ }^{2-}$ and alkalinity, which showed the highest contents and the concentrations of which increase steadily with depth, were responsible for this saline gradient. At the observed $\mathrm{pH}$ values alkalinity was present as $\mathrm{HCO}_{3}{ }^{-}$. Actually, the $\mathrm{pH}$ values fell within the range of 5.74 to 7.14 and are generally higher at the surface, except for lakes Tomeo and Inferiore where the values measured near the bottom were slightly higher. The mean oxygen saturation at the surface was around $100 \%$, while at the bottom it ranged between $48 \%$ (Alzasca) and $100 \%$ (Superiore). The hypolimnion of lakes Nero and Crosa, which are very deep (approx. $70 \mathrm{~m}$ ) and which are located above $2000 \mathrm{~m}$ a.s.l. in very remote areas, unexpectedly, had a rather low oxygen saturation level, 65 and $77 \%$, respectively.

\subsection{Biology of the lakes}

The list of phytoplankton species is given in table 6 . The taxa belonged to 7 classes of algae and have been determined to genus level, occasionally to species level. The undistinguished nanoplankton taxa were separated into two groups: flagellates and non-flagellates. Only the most representative taxa are discussed further.

In the lakes Crosa, Superiore and Inferiore a high number of species (between 16 and 22) was found, with relatively low abundance. In these lakes, no single species was dominant, and about 5-6 different species were well represented. In contrast, lakes Alzasca, Nero and Morghirolo were characterised by high abundance and a lower number of taxa (8-16); only one or two of these 
Tab. 5. Main characteristics of surface and bottom layers.

\begin{tabular}{|c|c|c|c|c|c|c|c|c|c|c|}
\hline Variables & Unit & Layer & Tomeo & Barone & Crosa & Superiore & Morghirolo & Inferiore & Nero & Alzasca \\
\hline \multirow[t]{2}{*}{ Temperature } & {$\left[{ }^{\circ} \mathrm{C}\right]$} & Surface & 13.6 & 11.0 & 12.5 & 11.8 & 12.0 & 11.8 & 10.8 & 15.4 \\
\hline & & Bottom & 5.8 & 4.0 & 4.2 & 5.2 & 4.6 & 4.2 & 4.0 & 4.2 \\
\hline \multirow[t]{2}{*}{ Cond. at $20^{\circ} \mathrm{C}$} & {$\left[\mu \mathrm{S} \mathrm{cm}^{-1}\right]$} & Surface & 8.81 & 9.43 & 7.23 & 8.03 & 10.64 & 9.00 & 14.73 & 14.50 \\
\hline & & Bottom & 10.15 & 10.83 & 9.14 & 8.98 & 11.05 & 17.30 & 18.90 & 20.37 \\
\hline \multirow[t]{2}{*}{ Density anomaly } & {$\left[\mathrm{mg} \mathrm{l}^{-1}\right]$} & Surface & -688 & -408 & -544 & -469 & -473 & -468 & -343 & -937 \\
\hline & & Bottom & -18 & 10 & 7 & -4 & 5 & 12 & 12 & 50 \\
\hline \multirow[t]{2}{*}{ Sulphate } & {$\left[\mathrm{mg} \mathrm{l}^{-1}\right]$} & Surface & 1.83 & 2.05 & 1.32 & 1.54 & 2.28 & 1.64 & 2.95 & 2.51 \\
\hline & & Bottom & 2.05 & 1.36 & 1.26 & 1.71 & 2.19 & 2.98 & 3.66 & 3.05 \\
\hline \multirow[t]{2}{*}{ Calcium } & {$\left[\mathrm{mg} \mathrm{l}^{-1}\right]$} & Surface & 0.95 & 1.26 & 1.05 & 1.04 & 1.38 & 1.18 & 2.18 & 2.08 \\
\hline & & Bottom & 1.17 & 2.19 & 1.43 & 1.26 & 1.31 & 2.38 & 2.78 & 2.71 \\
\hline \multirow[t]{2}{*}{ Bicarbonate } & {$\left[\mathrm{mg} \mathrm{l}^{-1}\right]$} & Surface & 0.25 & 0.72 & 0.91 & 1.51 & 2.12 & 1.71 & 3.99 & 4.29 \\
\hline & & Bottom & 0.75 & 0.98 & 1.77 & 2.07 & 2.34 & 4.90 & 5.33 & 6.83 \\
\hline \multirow[t]{2}{*}{$\mathrm{pH}$} & {$[-]$} & Surface & 5.7 & 6.3 & 6.4 & 6.6 & 6.8 & 6.6 & 7.2 & 6.9 \\
\hline & & Bottom & 5.9 & 5.8 & 6.2 & 6.5 & 6.3 & 7.0 & 6.5 & 6.4 \\
\hline \multirow[t]{2}{*}{ Oxygen sat. } & $\%$ & Surface & 100 & 101 & 106 & 99 & 110 & 105 & 110 & 111 \\
\hline & & Bottom & 96 & 84 & 77 & 100 & 78 & 91 & 65 & 48 \\
\hline
\end{tabular}

Tab. 6. Unitary biovolume of phytoplankton and crustacean zooplankton taxa. *refers to values from bibliography or estimated.

\begin{tabular}{|c|c|c|c|c|c|}
\hline $\begin{array}{c}\text { Phytoplankton } \\
\text { Taxa }\end{array}$ & $\begin{array}{l}\text { Biovolume } \\
{\left[\mu \mathrm{m}^{3} \text { ind }^{-1}\right]}\end{array}$ & $\begin{array}{c}\text { Phytoplankton } \\
\text { Taxa }\end{array}$ & $\begin{array}{l}\text { Biovolume } \\
{\left[\mu \mathrm{m}^{3} \text { ind }^{-1}\right]}\end{array}$ & $\begin{array}{c}\text { Zooplankton } \\
\text { Taxa }\end{array}$ & $\begin{array}{c}\text { Biovolume } \\
{\left[\mu \mathrm{m}^{3} 10^{6} \text { ind }^{-1}\right]}\end{array}$ \\
\hline Cyanophyceae & & Chlorophyceae & & Naupli & $5 \pm 2$ \\
\hline Aphanizomenon sp. * & 45 & Chlamydomonas sp.* & 1500 & Ciclopoida 1-2 & $12 \pm 7$ \\
\hline Oscillatoria sp. & 95 & Coenocystis sp. & $403 \pm 282$ & Ciclopoida 3-5 & $68 \pm 24$ \\
\hline Phormidium sp. & $204 \pm 21$ & Elakatothrix sp. & $526 \pm 114$ & Cyclops sp. male & $57 \pm 11$ \\
\hline Raphidiopsis sp. * & 25 & Oocystsis sp. & $131 \pm 44$ & Cyclops sp. female & $70 \pm 35$ \\
\hline Dactylococcopsis fascicularis & 25 & Tetraëdron sp. & $41 \pm 9$ & Cyclops abyss. tatr. male & $57 \pm 11$ \\
\hline Merismopedia sp. & 8 & Gonium spp.* & 344 & Cyclops abyss. tatr. female & $70 \pm 35$ \\
\hline Tetrapedia sp. * & 147 & Planktosphaeria sp. & 1500 & Paracyclops spp. male & $57 \pm 11$ \\
\hline Chrysophyceae & & Ulothricales $*$ & $219 \pm 35$ & Paracyclops spp. female & $70 \pm 35$ \\
\hline Dinobryon sp. & $552 \pm 158$ & Conjugatophyceae & & Daphnia longispina $*$ & 200 \\
\hline Mallomonas sp. & $1397 \pm 641$ & Closterium sp. & $3192 \pm 1485$ & Holopedium gibberum $*$ & 200 \\
\hline Chrysophyceae cysts & $805 \pm 623$ & Cosmarium cfr. tenue & $84 \pm 6$ & Alona sp. * & 44 \\
\hline Diatomeae & & Mougeotia sp. & $19506 \pm 5464$ & Acroperus harpae ${ }^{*}$ & 44 \\
\hline Surirella sp. & 19604 & Arthrodesmus sp. & $357 \pm 91$ & & \\
\hline Fragilaria spp. & $79 \pm 26$ & Gonatozygon sp. & $19085 \pm 5626$ & & \\
\hline Tabellaria sp.* & 529 & Micrasterias $\mathrm{sp} . *$ & 80000 & & \\
\hline Navicula sp. * & 100 & Cryptophyceae & & & \\
\hline Dinophyceae & & Cryptomonas sp. & $2484 \pm 1460$ & & \\
\hline Gymnodinium sp. & $1927 \pm 800$ & Rhodomonas minuta & $235 \pm 79$ & & \\
\hline Gymnodinium sp. small & $499 \pm 297$ & & & & \\
\hline Peridinium $\mathrm{sp.}$ & 2276 & Flagellated Nanoplankton & $83 \pm 32$ & & \\
\hline Peridinium cysts & $421 \pm 35$ & Non-flagellated Nanoplankton & $4 \pm 2$ & & \\
\hline
\end{tabular}

were dominant. Lake Barone was in an intermediate position with a number of species varying between 13 and 16 and with a relatively high abundance. In Lake Tomeo very few taxa (4-6) were found and one or two species were dominant.

Figure 2 illustrates seasonal dynamics of phytoplankton abundance, highlighting major seasonal differences within the algal groups; the lakes are classified in order of increasing alkalinity, i.e. from Tomeo $(8.4 \mu \mathrm{eq}$ $\left.1^{-1}\right)$ to Alzasca $\left(93.0 \mu \mathrm{eq} 1^{-1}\right)$. Among the cyanophyceans, Dactycoccopsis was prominent in lakes Nero, Alzasca and Morghirolo $\left(1000-6000 \times 10^{6}\right.$ cells $\left.\mathrm{m}^{-2}\right)$, while Raphidiopsis was found only in Nero $(18,000$ $22,500 \times 10^{6}$ cells $\mathrm{m}^{-2}$ ). Of the chrysophyceans, Dinobryon and Mallomonas were present in almost all the lakes $\left(20-600 \times 10^{6}\right.$ cells $\left.\mathrm{m}^{-2}\right)$ : Dinobryon was absent in Barone and showed an extraordinary bloom in Nero in August $\left(11000 \times 10^{6}\right.$ cells $\left.\mathrm{m}^{-2}\right)$; Mallomonas was not found in Tomeo or Nero. Chrysophycean cysts were numerically important, and were observed over the whole sampling period and in all the lakes (200$700 \times 10^{6}$ cells $\mathrm{m}^{-2}$ ). Of the diatoms, Fragilaria was present in lakes Morghirolo, Nero and Alzasca in high densities $\left(9000-97,000 \times 10^{6}\right.$ cells $\left.\mathrm{m}^{-2}\right)$. The dinophyceans were present everywhere with the small forms of Gymnodinium $\left(500-900 \times 10^{6}\right.$ cells $\mathrm{m}^{-2}$ ) and Peridinium (40$540 \times 10^{6}$ cells $\mathrm{m}^{-2}$ ), which showed a peak in September in Morghirolo $\left(2400 \times 10^{6}\right.$ cells $\left.\mathrm{m}^{-2}\right)$. Among the chlorophyceans, Tetraëdron was quite important in Nero and Morghirolo $\left(160-760 \times 10^{6}\right.$ cells $\left.\mathrm{m}^{-2}\right)$, and still more in 

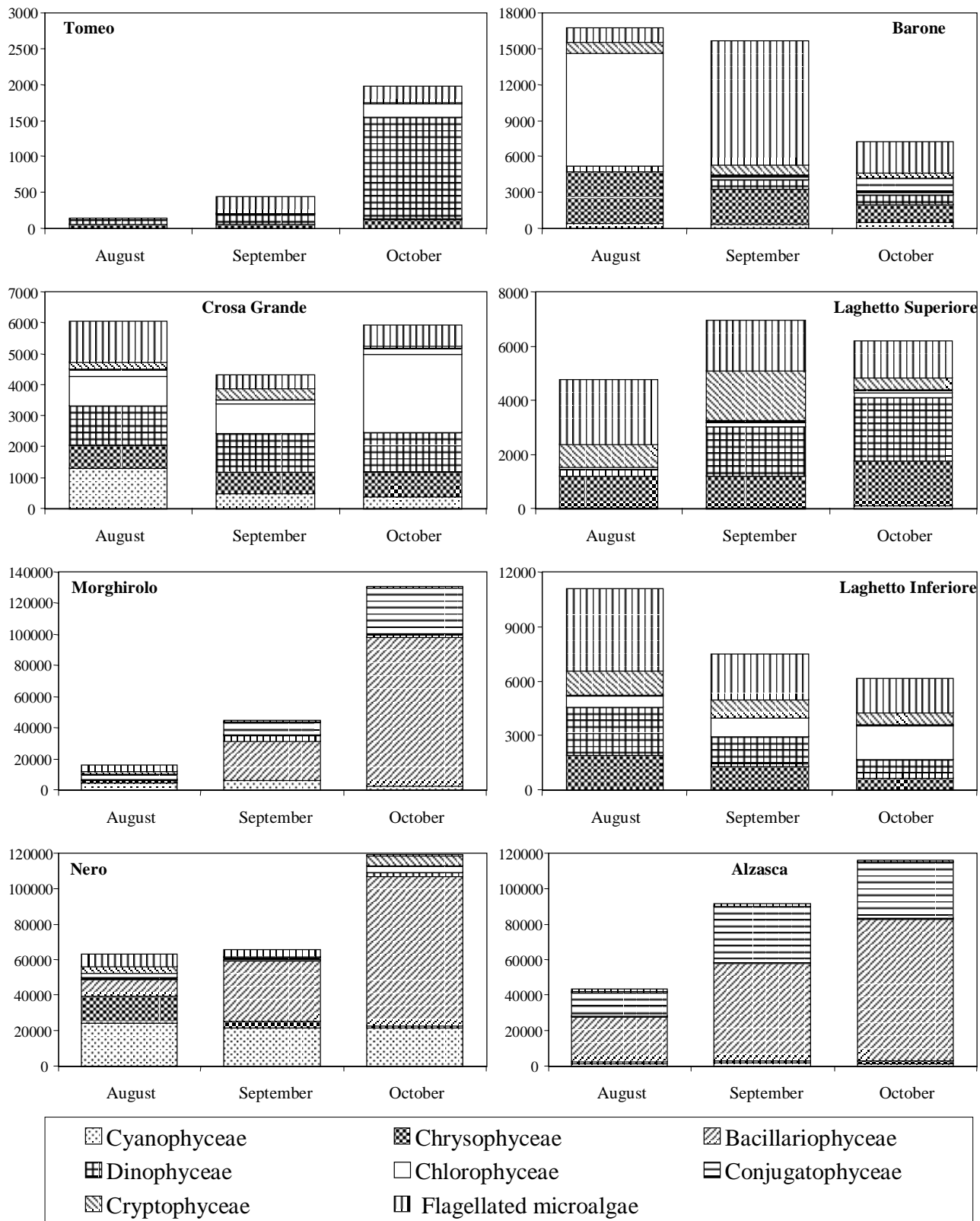

Fig. 2. Seasonal dynamics of abundances of the main phytoplankton groups [cell $10^{6} \mathrm{~m}^{-2}$ ], shown in order of increasing alkalinity, from Tomeo to Alzasca.

Inferiore $\left(400-1900 \times 10^{6}\right.$ cells $\left.\mathrm{m}^{-2}\right)$. Oocystis was found in Crosa $\left(70-1150 \times 10^{6}\right.$ cells $\left.\mathrm{m}^{-2}\right)$, and only occasionally in the other lakes, while Elakatothrix was observed only in Crosa $\left(290-790 \times 10^{6}\right.$ cells $\left.\mathrm{m}^{-2}\right)$, Inferiore and Superiore $\left(20-140 \times 10^{6}\right.$ cells $\left.\mathrm{m}^{-2}\right)$. Planktosphaeria was present in Crosa and Inferiore $\left(30-100 \times 10^{6}\right.$ cells $\left.\mathrm{m}^{-2}\right)$ and in Barone, where there was a strong development in August $\left(8600 \times 10^{6}\right.$ cells $\left.\mathrm{m}^{-2}\right)$. Among conjugatophyceans, the density of Cosmarium cf. tenue was very high in lakes Alzasca and Morghirolo (3400-31800 $\times 10^{6}$ cells $\left.\mathrm{m}^{-2}\right)$ and high in Nero $\left(380-4000 \times 10^{6}\right.$ cells $\left.\mathrm{m}^{-2}\right)$. Arthrodesmus was found in Barone, Crosa, Superiore and Infe- riore $\left(10-230 \times 10^{6}\right.$ cells $\left.\mathrm{m}^{-2}\right)$. Finally, of the class of cryptophyceans, Cryptomonas was present in all the lakes, except of Tomeo, at the densities of 260 to 850 $10^{6} \times$ cells $\mathrm{m}^{-2}$, reaching higher densities $\left(1200-2900 \times 10^{6}\right.$ cells $\mathrm{m}^{-2}$ ) in lakes Superiore, Inferiore and Nero. Rhodomonas was found in Inferiore $\left(80-350 \times 10^{6}\right.$ cells $\left.\mathrm{m}^{-2}\right)$ and Nero (up to $5200 \times 10^{6}$ cells $\mathrm{m}^{-2}$ ). Nanoplanktonic flagellates and non-flagellates, were common in all the lakes, except Tomeo, at the densities of 600 to $3400 \times 10^{6}$ cells $\mathrm{m}^{-2}$.

The list of zooplankton species is given in table 6 . Three crustacean species with high density were found 
in Crosa and Alzasca. In Superiore and Tomeo the three taxa were also present, but with considerably lower abundance. In Barone, there were two species with very low density, and in the rest of lakes, Morghirolo, Nero and Inferiore, only one taxon occurred, with high abundance in the first two lakes, but it was scarce in the third.

The zooplankton taxa belonged to the groups of copepods and cladocerans, at different stages of development. Figure 3 illustrates the monthly variation of crustacean zooplankton abundance. Copepods were found in all the lakes, while cladocerans only attained high values in the lakes Crosa and Alzasca, and lower values were found in Superiore. The greatest copepod numbers (up to 100,000 ind $\mathrm{m}^{-2}$ ) were found in Nero, though they were mostly larvae and juveniles (nauplii, copepodites C1-2 and C3-5). The greatest quantities of adults occurred in Crosa, Morghirolo, Nero and Alzasca (400021,000 ind $\mathrm{m}^{-2}$ ). Cyclops abyssorum tatricus was found in Superiore (200-2900 ind $\mathrm{m}^{-2}$ ) and Inferiore (young stages only). In Crosa the cladocerans were represented mainly by Daphnia longispina (1000-85,000 ind $\left.\mathrm{m}^{-2}\right)$, while Holopedium gibberum predominated in Alzasca $\left(18,500-64,600\right.$ ind $\left.\mathrm{m}^{-2}\right)$.

For a quantitative intercomparison, the fresh biomass values were calculated by multiplying the plankton taxa abundance by the relative biovolume per individual (Tab. 6). The distribution of biomass values in lakes was considerably different from that of abundance.
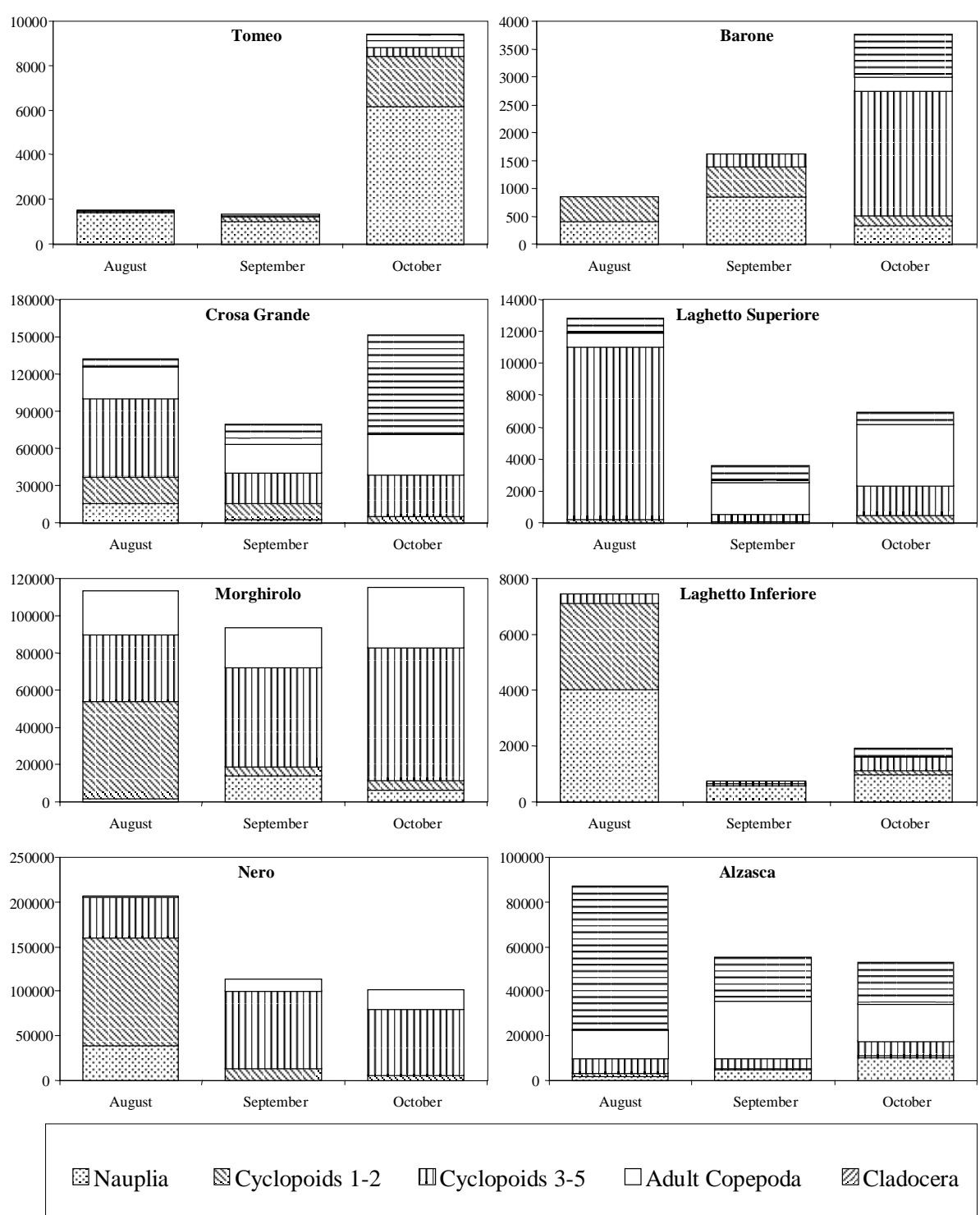

Fig. 3. Seasonal dynamics of abundance of crustacean zooplankton [ind. $\mathrm{m}^{-2}$ ], shown in order of increasing alkalinity, from Tomeo to Alzasca. 
Table 7 shows the mean phytoplankton biomass values with the relative standard deviation. Nero and Barone had the greatest average biomass (12.8-13.0 $\left.\mathrm{g} \mathrm{m}^{-2}\right)$, followed by Morghirolo, Alzasca, Superiore and Inferiore, with values between 5.6 and $9.5 \mathrm{~g} \mathrm{~m}^{-2}$. Crosa and Tomeo had the lowest biomass $\left(3.6\right.$ and $0.8 \mathrm{~g} \mathrm{~m}^{-2}$, respectively).

In Barone, the chlorophyceans were quantitatively important in August $\left(13.7 \mathrm{~g} \mathrm{~m}^{-2}\right)$, the conjugatophyceans in September $\left(6.8 \mathrm{~g} \mathrm{~m}^{-2}\right)$, and the chrysophyceans were important throughout the whole sampling period. The chrysophyceans were also dominant in Nero $\left(9.8 \mathrm{~g} \mathrm{~m}^{-2}\right)$, equally to the cryptophyceans, especially in August. Diatoms and dinophyceans predominated alternatively in Morghirolo, the first in particular in September with a peak of $7.6 \mathrm{~m}^{-2}$. Dinophyceans, cryptophyceans and chrysophyceans made up about $70 \%$ of the algal biomass in Superiore and Inferiore, distributed evenly over the three months. The diatom biomass was important in Alzasca, whereas dinophyceans and chlorophyceans dividual samplings were found in lakes Alzasca (14.2 $\mathrm{g}$ $\mathrm{m}^{-2}$ ) and Crosa $\left(20.5 \mathrm{~g} \mathrm{~m}^{-2}\right)$.

In Morghirolo and Nero, young and adult copepods made up to $90 \%$ of the total biomass during the whole observation period, while they achieved around $75 \%$ of the total in Barone and Superiore. Copepod larvae and juveniles were dominant in Tomeo and Inferiore, with $75 \%$ and $89 \%$ of total biomass, respectively. The highest cladoceran biomass were found in Crosa and Alzasca, where they represented $60-80 \%$ of the total. As regards the seasonal trend, Tomeo and Superiore showed the highest peaks in October $\left(0.1\right.$ and $2.0 \mathrm{~g} \mathrm{~m}^{-2}$, respectively), Inferiore and Superiore in August (0.1 and $1.0 \mathrm{~g} \mathrm{~m}^{-2}$ ). The highest values of total biomass were found in Alzasca during August (14.2 $\mathrm{g} \mathrm{m}^{-2}$ ) and during October in Crosa $\left(20.5 \mathrm{~g} \mathrm{~m}^{-2}\right)$.

\section{DISCUSSION}

The ionic content of the 8 lakes revealed a slight increase in saline concentration in the whole water col-

Tab. 7. Seasonal mean biomass of main phytoplankton and zooplankton groups $\left[\mathrm{mg} \mathrm{m}^{-2}\right]$.

\begin{tabular}{|c|c|c|c|c|c|c|c|c|}
\hline PHYTOPLANKTON & Tomeo & Barone & Crosa & Superiore & Morghirolo & Inferiore & Nero & Alzasca \\
\hline Cyanophyceae & & $20 \pm 14$ & $59 \pm 65$ & $3 \pm 4$ & $120 \pm 42$ & & $561 \pm 31$ & $38 \pm 8$ \\
\hline Chrysophyceae & $64 \pm 27$ & $3086 \pm 1713$ & $759 \pm 131$ & $1574 \pm 526$ & $425 \pm 251$ & $1004 \pm 562$ & $4344 \pm 4776$ & $1529 \pm 206$ \\
\hline Diatomeae & $7 \pm 6$ & $26 \pm 45$ & $26 \pm 0$ & $7 \pm 5$ & $3200 \pm 3917$ & $8 \pm 5$ & $3346 \pm 3011$ & $4225 \pm 2176$ \\
\hline Dinophyceae & $610 \pm 888$ & $525 \pm 268$ & $1206 \pm 218$ & $2057 \pm 1599$ & $3046 \pm 2947$ & $2062 \pm 939$ & $868 \pm 535$ & $369 \pm 68$ \\
\hline Chlorophyceae & $24 \pm 39$ & $4631 \pm 7862$ & $900 \pm 419$ & $75 \pm 44$ & $18 \pm 26$ & $94 \pm 9$ & $178 \pm 294$ & $11 \pm 19$ \\
\hline Conjugatophyceae & $40 \pm 8$ & $2321 \pm 3881$ & $78 \pm 30$ & $567 \pm 500$ & $1141 \pm 1167$ & $193 \pm 100$ & $155 \pm 156$ & $2133 \pm 906$ \\
\hline Cryptophyceae & $7 \pm 10$ & $1758 \pm 473$ & $526 \pm 308$ & $2517 \pm 1674$ & $1394 \pm 1036$ & $1940 \pm 1064$ & $3269 \pm 3644$ & $715 \pm 833$ \\
\hline Flag. microalgae & $13 \pm 11$ & $392 \pm 415$ & $67 \pm 38$ & $155 \pm 42$ & $187 \pm 161$ & $248 \pm 117$ & $305 \pm 247$ & $99 \pm 13$ \\
\hline Nanoplankton & & $5 \pm 5$ & $8 \pm 7$ & $8 \pm 3$ & $2 \pm 2$ & $15 \pm 0$ & $1 \pm 2$ & $34 \pm 37$ \\
\hline Edible biomass & $658 \pm 880$ & $2568 \pm 4083$ & $927 \pm 207$ & $2501 \pm 2065$ & $5587 \pm 5619$ & $2263 \pm 840$ & $1798 \pm 3624$ & $4478 \pm 3017$ \\
\hline Total biomass & $766 \pm 963$ & $12764 \pm 8747$ & $3629 \pm 272$ & $6963 \pm 3004$ & $9534 \pm 4177$ & $5558 \pm 2568$ & $13029 \pm 6759$ & $9153 \pm 2353$ \\
\hline \multicolumn{9}{|l|}{ ZOOPLANKTON } \\
\hline Naupli & $14 \pm 14$ & $3 \pm 1$ & $31 \pm 42$ & & $37 \pm 31$ & $9 \pm 9$ & $65 \pm 112$ & $28 \pm 21$ \\
\hline Ciclopoida 1-2 & $10 \pm 15$ & $5 \pm 2$ & $158 \pm 97$ & $3 \pm 3$ & $253 \pm 331$ & $13 \pm 21$ & $567 \pm 780$ & $11 \pm 5$ \\
\hline Ciclopoida 3-5 & $12 \pm 15$ & $55 \pm 84$ & $2784 \pm 1421$ & $299 \pm 385$ & $3647 \pm 1189$ & $20 \pm 14$ & $4703 \pm 1422$ & $395 \pm 88$ \\
\hline Copepoda adults & $8 \pm 9$ & $5 \pm 8$ & $1642 \pm 338$ & $135 \pm 93$ & $1650 \pm 421$ & & $778 \pm 706$ & $1173 \pm 450$ \\
\hline Cladocera & $5 \pm 7$ & $11 \pm 20$ & $6828 \pm 8096$ & $117 \pm 67$ & & $5 \pm 8$ & & $6881 \pm 5232$ \\
\hline Herbivores & $29 \pm 36$ & $19 \pm 17$ & $7017 \pm 7975$ & $120 \pm 65$ & $290 \pm 306$ & $28 \pm 27$ & $632 \pm 892$ & $6920 \pm 5221$ \\
\hline Total biomass & $48 \pm 60$ & $79 \pm 109$ & $11443 \pm 7870$ & $555 \pm 367$ & $5587 \pm 1316$ & $48 \pm 35$ & $6113 \pm 1096$ & $8488 \pm 4940$ \\
\hline
\end{tabular}

were more important in Crosa. Neither of this two lakes showed marked seasonal differences in the biomass of single algal groups, although in Alzasca the total biomass increased from $6.9 \mathrm{~g} \mathrm{~m}^{-2}$ in August to $11.6 \mathrm{~g} \mathrm{~m}^{-2}$ in October. Finally, Tomeo was characterised by a massive presence of dinophyceans, especially in October $(1.6 \mathrm{~g}$ $\mathrm{m}^{-2}$ ); they made up to $80 \%$ of the total biomass.

Concerning the zooplankton biomass (Tab. 7), the lakes may be divided into three distinct groups: Nero, Morghirolo, Alzasca and Crosa Grande had mean total biomass between 6.1 and $11.4 \mathrm{~g} \mathrm{~m}^{-2}$, while Tomeo, Morghirolo and Inferiore had very low values, below $0.1 \mathrm{~g} \mathrm{~m}^{-2}$. Superiore fell between these extremes with a mean biomass of $0.6 \mathrm{~g} \mathrm{~m}^{-2}$. The maximum values of in- umn during the vegetative period (around $+5 \%$ ). The presence of a density gradient along the column (increase of around $20 \%$ from the surface to the bottom) was revealed using the concept of density anomaly ( $\rho$ 1). The stratification phenomenon can be explained by a very sudden warming after the thaw, without circulation, by the fact that the lakes are in a position sheltered from the wind, or by a very low surface to depth ratio. Furthermore, chemical stratification could be strengthened by the long water residence time, the longer contact with bedrock, or some groundwater seepage from the slopes of the lake bottom. This vertical density gradient tends to hinder the dimictic behaviour typical of these waterbodies: in fact, the deeper lakes can show an 
oxygen saturation rate in the hypolimnion below $70 \%$, despite their low level of productivity. Meromixis could be presumed to exist in some of the lakes, although further studies would be required to conform this hypothesis.

The eight lakes have alkalinity values below $90 \mu \mathrm{eq}$ $1^{-1}$, and can therefore be regarded as sensitive to acid deposition. The lowest $\mathrm{pH}$ value was measured in Tomeo (an average of 5.9), and can be related to the short renewal time of its water (30 days; see table 1), and to the characteristics of the cover in its watershed (crystalline rocks, little vegetation; see table 2). The highest $\mathrm{pH}$ (an average of 7.0) was measured in Alzasca, which has more vegetation cover and a longer water renewal time (171 days), and in Nero, which has the longest renewal time (533 days).

Low $\mathrm{pH}$ values induce aluminium dissolution from the watershed rocks, and according to some authors, this means an increase in toxicity for fish (Rask et al. 1992). Reactive aluminium is found in quite high concentrations only in the Tomeo water column, with Inferiore and Superiore showing lower concentrations. Figure 4 illustrates the concentrations measured at various depths in these three lakes and reports the relative thermodynamic stability of four different types of hydroxides of this element (Stumm \& Morgan 1981; Psenner et al. 1988). The graph shows that in Tomeo the dissolved form was probably represented by $\mathrm{Al}(\mathrm{OH})_{2}{ }^{+}$in a metastable state (not in equilibrium) or there were other ions interacting with $\mathrm{Al}\left(\mathrm{SO}_{4}{ }^{2-}\right.$ and $\left.\mathrm{F}^{-}\right)$, while in Inferiore and Superiore it was $\mathrm{Al}(\mathrm{OH})_{4}$.

The relations between the chemical parameters of the eight lakes were verified statistically on the basis of an analysis of their correlation matrix (Tab. 8). As re-

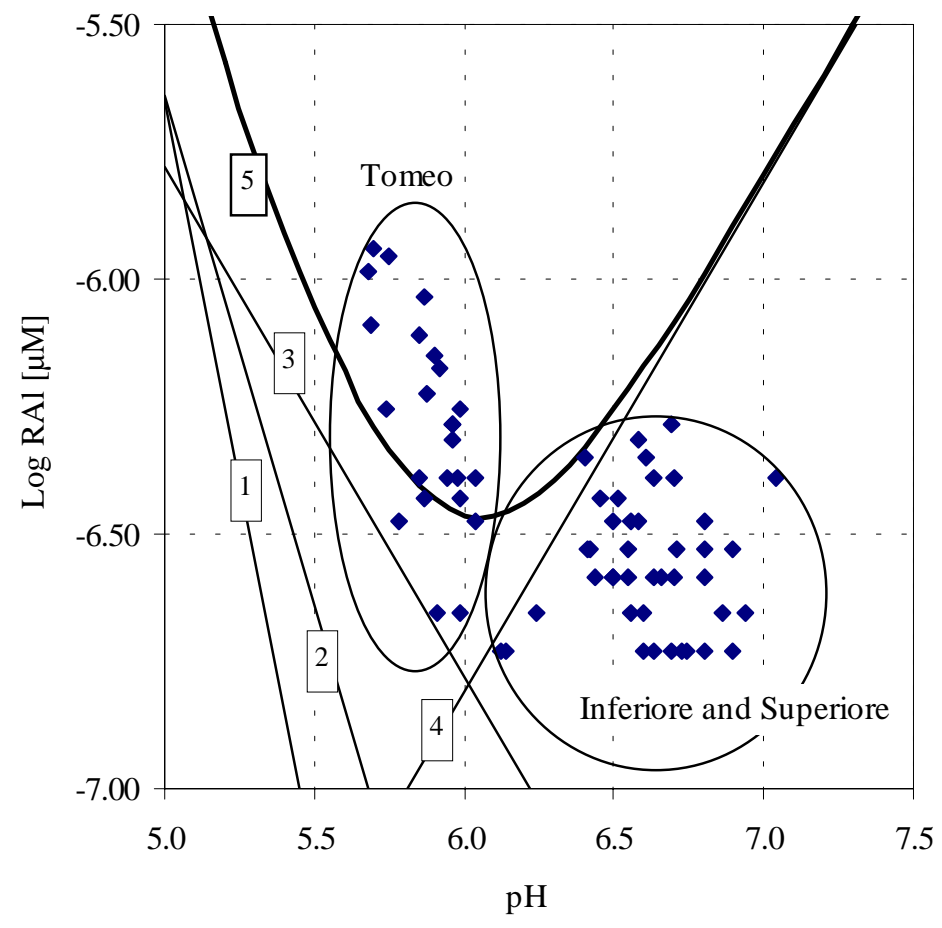

Fig. 4. Reactive aluminium concentration versus $\mathrm{pH}$ for lakes Tomeo, Inferiore and Superiore. Solubility equilibrium lines for aluminium hydroxides $\left(1=\mathrm{Al}^{3+}\right.$; $2=\mathrm{AlOH}^{2+} ; 3=\mathrm{Al}(\mathrm{OH})_{2}{ }^{+} ; 4=\mathrm{Al}(\mathrm{OH})_{4}^{-} ; 5=$ total $\left.\mathrm{Al}\right)$ are also reported.

Tab. 8. Correlation matrix between the main chemical parameters. Significant (at $p<0.05$ ) correlations are in bold letters.

\begin{tabular}{lccccccccccc}
\hline & $\mathrm{pH}$ & Cond & $\mathrm{Ca}^{2+}$ & $\mathrm{Mg}^{2+}$ & $\mathrm{Na}^{+}$ & $\mathrm{K}^{+}$ & Alk & $\mathrm{SO}_{4}{ }^{2-}$ & $\mathrm{NO}_{3}{ }^{-}-\mathrm{N}$ & $\mathrm{Cl}^{-}$ & $\mathrm{SiO}_{2}$ \\
\hline $\mathrm{pH}$ & 1.00 & 0.69 & $\mathbf{0 . 7 6}$ & $\mathbf{0 . 8 0}$ & 0.48 & $\mathbf{0 . 9 2}$ & $\mathbf{0 . 8 7}$ & 0.61 & $\mathbf{- 0 . 8 8}$ & -0.13 & 0.32 \\
Cond & & 1.00 & $\mathbf{0 . 9 8}$ & $\mathbf{0 . 8 8}$ & $\mathbf{0 . 8 5}$ & $\mathbf{0 . 8 1}$ & $\mathbf{0 . 9 4}$ & $\mathbf{0 . 9 3}$ & -0.38 & 0.48 & $\mathbf{0 . 7 6}$ \\
$\mathrm{Ca}^{2+}$ & & & 1.00 & $\mathbf{0 . 8 5}$ & $\mathbf{0 . 7 7}$ & $\mathbf{0 . 8 2}$ & $\mathbf{0 . 9 6}$ & $\mathbf{0 . 9 1}$ & -0.47 & 0.37 & 0.67 \\
$\mathrm{Mg}^{2+}$ & & & & 1.00 & $\mathbf{0 . 7 7}$ & $\mathbf{0 . 8 6}$ & $\mathbf{0 . 9 2}$ & $\mathbf{0 . 7 6}$ & -0.56 & 0.40 & $\mathbf{0 . 7 4}$ \\
$\mathrm{Na}^{+}$ & & & & & 1.00 & $\mathbf{0 . 7 1}$ & $\mathbf{0 . 7 8}$ & 0.67 & -0.04 & $\mathbf{0 . 7 1}$ & $\mathbf{0 . 8 7}$ \\
$\mathrm{K}^{+}$ & & & & & & 1.00 & $\mathbf{0 . 9 0}$ & $\mathbf{0 . 7 4}$ & $\mathbf{- 0 . 7 0}$ & 0.07 & 0.46 \\
$\mathrm{Alk}^{+}$ & & & & & & & 1.00 & $\mathbf{0 . 8 1}$ & -0.59 & 0.32 & 0.67 \\
$\mathrm{SO}_{4}{ }^{2-}$ & & & & & & & & 1.00 & -0.43 & 0.27 & 0.57 \\
$\mathrm{NO}_{3}{ }^{-} \mathrm{N}$ & & & & & & & & & 1.00 & 0.51 & 0.08 \\
$\mathrm{Cl}^{-}$ & & & & & & & & & & 1.00 & $\mathbf{0 . 8 3}$ \\
$\mathrm{SiO}_{2}$ & & & & & & & & & & & 1.00 \\
\hline
\end{tabular}


gards the chemical parameters, $\mathrm{pH}$ and conductivity were correlated significantly with almost all the other variables. Alkalinity was closely correlated with calcium, magnesium and sulphate because of carbonate weathering, while silicate was correlated with sodium and chloride because of silicate weathering (Fig. 5). Ni- nitrogenous forms shows practically equivalent concentrations for nitrate and ammonium, around $15 \mu \mathrm{eq} \mathrm{l}^{-1}$ (Barbieri \& Mosello 1999). However, ammonium concentrations in lake water were always close to the LOQ, which suggests that the phenomena of oxidation and/or uptake bring about a complete transformation of this

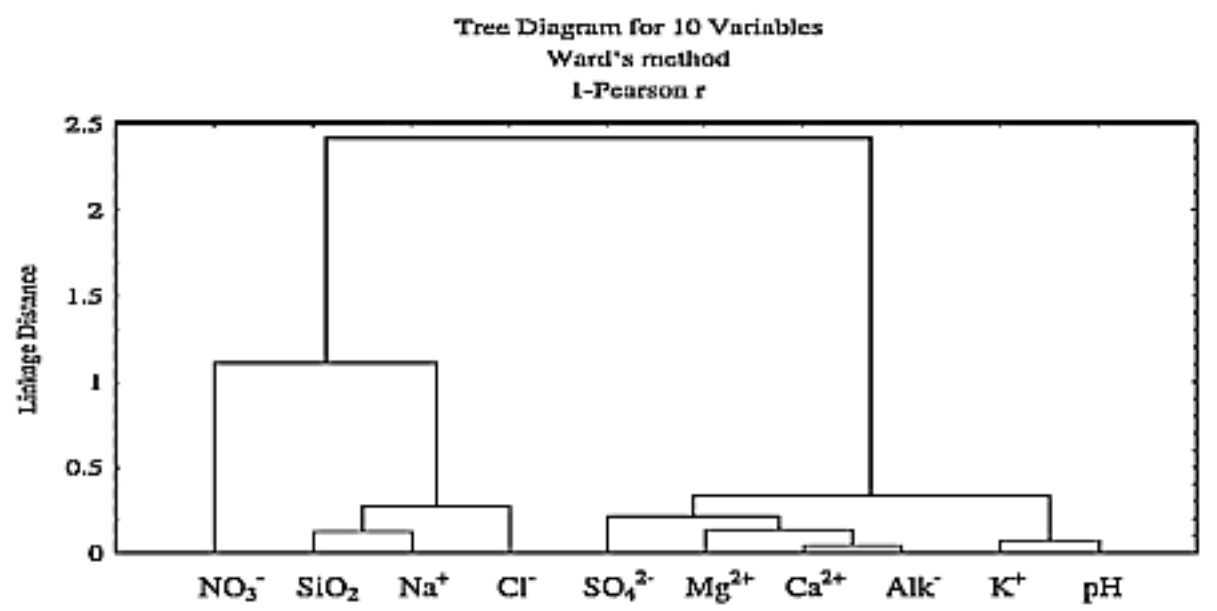

Fig. 5. Classification of the chemical characteristics of the eight lakes using cluster analysis (Ward's method, Pearson r).

trate was negatively correlated with all the variables, but significantly only with $\mathrm{pH}$ and potassium. In lakes where the $\mathrm{pH}$ values were between 6.5 and 7.0, the nitrate concentrations were between 10 and $15 \mu \mathrm{eq} \mathrm{l}^{-1}$, while in lakes with $\mathrm{pH}$ between 6.5 and 5.8 the nitrate concentrations increased up to $26 \mu \mathrm{eq}^{-1}$ (Fig. 6).

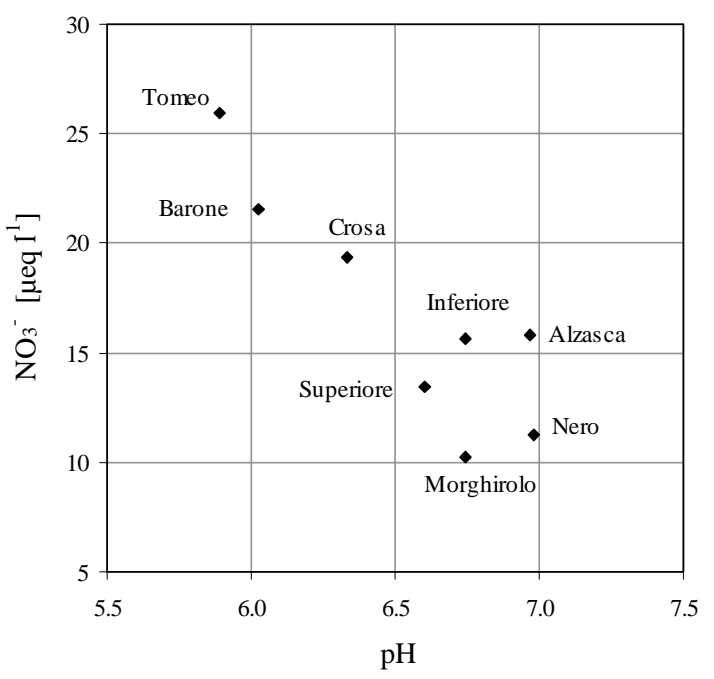

Fig. 6. Mean seasonal nitrate concentrations versus $\mathrm{pH}$.

The interpretation of this behaviour is complex, and must take into consideration the origin of the nitrate sources and their transformation in the catchment and in the lake. At high altitudes, the atmospheric deposition of ion. A complete oxidation to nitrate yields two acidity equivalents for each ammonium equivalent. This acidity, added to that present in deposition (Barbieri \& Mosello 1999), consumes alkalinity produced by weathering in the catchment, which in its turn depends on the geology of rocks of which it is formed. In lakes where the alkalinity was low (Tomeo, Barone, Crosa), it was consumed to high degree, causing a considerable drop in the $\mathrm{pH}$ of the water. In acidified waters $(\mathrm{pH}<6.5)$, biological activity might be partially inhibited, also due to the presence of dissolved aluminium, and consequently an algal nutrient like nitrate is only partially used. Nitrate concentrations thus showed higher values in acid than in non-acid lakes $(\mathrm{pH}>6.5)$.

The $\mathrm{pH}$ and the alkalinity of the water can in their turn be related to the structure of the phytoplankton biocenosis. If we consider the lakes in order of increasing alkalinity, we can see a progressive shift in biomass composition. In the lakes with low alkalinity (8-40 $\mu$ eq $1^{-1}$ ) there was a dominance of dinophyceans $(30-80 \%)$ and chlorophyceans (25-30\%), while diatoms were absent (Pfister \& Psenner 1988; Thaler et al. 1991): the dinophyceans, especially the genus Peridinium, are in fact regarded as a particularly resistant algal group, and also the group with mixotrophic and even phagotrophic species (Stokes 1986; Pfister \& Psenner 1988; Baker et al. 1990; Jones 1994). In contrast, the diatoms were present in lakes with higher alkalinity (40-90 $\mu$ eq $1^{-1}$ ), where they formed $20-60 \%$ of the total biomass. The cryptophyceans and the chrysophyceans appeared to be able to adapt to all alkalinity levels. 
Composition of phytoplankton assemblage in the lakes investigated corresponded to previous findings from alpine lakes in the Ticino Canton (Schneider 1981), and it was also in concordance with the results from Lago Paione Superiore (Italian Alps - Pugnetti \& Bettinetti 1999, this issue) where the most important groups, both in abundance and in biomass, were chrysophyceans (Chromulina, Dinobryon, Mallomonas) and dinophyceans (Gymnodinium). Those two groups were also prevailing in Tatra Mountains (Slovak Carpathians) in non-acidified Lake Nižné Terianske (Fott et al. 1999, this issue).

Zooplankton composition also was characteristic for mountain lakes in the Alps and Carpathians (Tatra Mountains): Cyclops abyssorum tatricus prevailing (Fott et al. 1992; Manca \& Comoli 1999, this issue).

Crustacean zooplankton biomass showed a pattern, apparently independent on the availability of edible phytoplankton (Tab. 7). This might be connected with an increased predatory pressure on zooplankton in some lakes, while they are restocked with fish every year by fishing associations.

It should be borne in mind that the pelagic population structure in these lakes also depends on the seasonal meteorological and hydrological trend. In any case the results of this survey substantially confirmed the results of previous studies on the Alpine lakes of the Ticino Canton (Schneider 1981).

A further comparison among the lakes as regards the overall quality of their phytoplankton biocenoses was made on the basis of biodiversity. In a comparative review by Washington (1984) of the most common biotic indices, the index of probability of interspecific encounters (PIE; Hurlbert 1971) was considered to be one of the most suitable for investigating aquatic ecosystems. For this reason we applied this PIE index which establishes the probability of encounters between two individuals of different species, assuming that every individual in the collection can encounter all the other individuals. This index has a low sensitivity for rare species and gives high importance to the evenness of distribution of individuals between the different species.

$$
P I E=\left[\frac{N}{N+1}\right] \cdot\left[1-\sum_{i}\left(\frac{N_{i}}{N}\right)^{2}\right]
$$

$N$ is the total number of individuals and $N_{i}$ the number of individuals in the $i^{\text {th }}$ species. Unicellular organisms and colonial aggregates are considered as single individuals.

The monthly values of the index are reported in table 9. Crosa, Inferiore and Superiore showed a high mean phytoplankton PIE, between 0.78 and 0.88 , reflecting the fairly homogenous distribution of individuals of all species. In these three lakes the density structure and the PIE value remain fairly constant in time. Alzasca showed the lowest PIE (0.5), with the continuous domi- nance of one species (and of a second, to a lesser extent) for the whole length of the period. Tomeo had a value of 0.65 and was fairly constant in time. The October increase in this lake was due to a rise in the number of species, although limited by the fact that one taxon had become dominant.

Tab. 9. Phytoplankton PIE (probability of interspecific encounters) values in the eight investigated lakes.

\begin{tabular}{lcccc}
\hline & August & September & October & Average \\
\hline Crosa & 0.86 & 0.87 & 0.90 & 0.88 \\
Inferiore & 0.78 & 0.83 & 0.81 & 0.81 \\
Superiore & 0.69 & 0.81 & 0.82 & 0.78 \\
Barone & 0.68 & 0.55 & 0.82 & 0.69 \\
Tomeo & 0.63 & 0.64 & 0.69 & 0.65 \\
Nero & 0.78 & 0.63 & 0.48 & 0.63 \\
Morghirolo & 0.78 & 0.63 & 0.42 & 0.61 \\
Alzasca & 0.57 & 0.52 & 0.47 & 0.52 \\
\hline
\end{tabular}

The other three lakes had biodiversity indexes (PIE), which showed greater fluctuations in time, with monthly values between 0.55 and 0.78 . In Nero and Morghirolo the PIE tended to decrease as one population was seen to gradually assert its dominance over the others, even though the number of species remained constant. In Barone the index fluctuated, with a tendency to increase as the dominant species decreased. In the range of lakes studied, any simple correlation of the PIE index (calculated for phytoplankton assemblage) with $\mathrm{pH}$, alkalinity or conductivity was not found to be significant.

\section{CONCLUSIONS}

High altitude Alpine lakes vary greatly in their geomorphological characteristics, which can have a considerable effect on the dynamics of their physical, chemical and biological processes. While remaining linked to classic hydrological parameters, the water mixing process is particularly dependent on the annual precipitation regime and on the maximum depth of the lakes. Most of the lakes are fairly deep $(>30 \mathrm{~m})$, and display a weak vertical saline gradient, which is, however, theoretically able to prevent a complete annual overturn. Only particularly intense rainfall events during the period of homothermy are sometimes able to cause a mixing of the lake waters right to the bottom (Barbieri \& Mosello 1999). In half of the lakes the reduced tendency to mixing is revealed by a dissolved oxygen saturation rate ranging between 50 and $80 \%$ in the water layers below a depth of $30 \mathrm{~m}$.

The chemical composition of the waters largely reflected that of the geological substrate and the petrographic composition of the soil: two ion aggregations in particular may be distinguished, deriving from the weathering of carbonates and silicates. The ion contribution of atmospheric deposition, while considerable, did not seem to change significantly the overall picture of the lake water chemistry. 
The $\mathrm{pH}$ of the lakes ranged from values which were slightly acid (5.8-6.5) to neutral values (6.5-7.0). Of the metals studied, only aluminium showed behaviour significantly affected by $\mathrm{pH}$, with measurable concentrations in the form of $\mathrm{Al}(\mathrm{OH})_{2}{ }^{+}$for $\mathrm{pH}$ lower than 5.9, and in the form of $\mathrm{Al}(\mathrm{OH})_{4}{ }^{-}$for $\mathrm{pH}$ higher than 6.6. In the slightly acid lakes it seems possible that there was a reduction in biological activity, due to $\mathrm{pH}$ and aluminium, with consequently lower consumption of nitrate by phytoplankton. This situation was revealed in a negative correlation between the nitrate concentration and the $\mathrm{pH}$ value. As for the algal biocenosis, dinophyceans and chlorophyceans predominated in lakes with low $\mathrm{pH}$ and alkalinity values, whereas diatoms were present in lakes where the values of these parameters are higher.

Although the area of study was geographically limited $(20 \mathrm{~km} \times 20 \mathrm{~km})$, the composition of the phytoplankton community in the studied lakes showed considerable differences, both as regards the number of species and their percentage contribution. Actually, the PIE diversity index ranged between 0.42 and 0.90 . This must be seen in relation to the different geomorphological, hydrochemical and hydrological characteristics of the lakes and their watersheds.

The mean algal biomass values, calculated on the basis of three samplings (August-October 1997), ranged between 3.6 and $13.0 \mathrm{mg} \mathrm{m}^{-2}$ in 7 of the lakes; in the eighth (Tomeo), which is characterised by a short renewal time (30 days) and a low $\mathrm{pH}$ (5.9), the values were $0.7 \mathrm{mg} \mathrm{m}^{-2}$.

Crustacean zooplankton was present in all the lakes with a limited number of species (from 1 to 3 ). The low plankton biomass values found in these lakes might be due to a combination of factors, such as the natural oligotrophy of the waters, acidity of anthropogenic origin, and washout episodes, as well as the introduction of fish by local fishing associations.

\section{REFERENCES}

A.A.V.V. 1980. Guidelines for data acquisition and data quality evaluation in environmental chemistry. Anal. Chem., 52: 2242-2249.

Analytical Methods Committee. 1987. Recommendations for the definition, estimation and use of detection limit. Analyst, 112: 199-204.

Baker, J.P., D.P. Bernard, S.W. Christensen, M.J. Sale, J. Freda, K. Heltcher, D. Marmorek, L. Rowe, P. Scanlon, G. Suter, W. Warrenhicks \& P. Welbourn. 1990. Biological effects of changes in surface water acid-base chemistry. NAPAP Report 13. In: P.M. Irving (Ed.), National acid precipitation assessment program. Acidic deposition: state of science and technology. Vol II: 1-381.

Barbieri, A. \& R. Mosello. (1999). Recent evolution in chemistry and mass budget of a high altitude lake in southern Alps (Laghetto Inferiore, Switzerland). J. Limnol.: (submitted).

Boggero, A., A. Barbieri, J. de Long, A. Marchetto \& R. Mosello. 1998. Chemistry and critical loads of Alpine lakes in Canton Ticino (Southern Central Alps). Aquatic Sci., 60: 300-315.

Boggero, A., A. Marchetto, A. Barbieri, A. Sassi, M. Conedera, G. A. Tartari \& R. Mosello. 1996. Idrochimica dei laghi alpini del Canton Ticino (Alpi Centrali) in relazione con la chimica delle precipitazioni. Documenta Ist. Ital. Idrobiol., 57: $273 \mathrm{pp}$.

Cotti, G., M. Felber, A. Fossati, G. Lucchini, E. Steiger \& P. L. Zanon. 1990. Introduzione al paesaggio naturale del Cantone Ticino. 1. Le componenti naturali. Dipartimento dell'ambiente, Cantone Ticino: $485 \mathrm{pp}$.

Fott, J., M. Blažo, E. Stuchlík \& O. Strunecký. 1999. Phytoplankton in three Tatra mountain lakes of different acidification status. In: Straškrabová, V., C. Callieri \& J Fott (Eds), Pelagic food web in mountain lakes. MOuntain LAkes Research Program. J. Limnol., 58(2): 107-116.

Fott, J., E. Stuchlík, Z. Stuchlíková, V. Straškrabová, J. Kopáček \& K. Šimek. 1992. Acidification of lakes in Tatra Mountains (Czechoslovakia) and its ecological significance. In: Mosello, R., Wathne, B. \& Giussani, G. (Eds), Limnology on groups of remote mountain lakes: ongoing and planned activities. Documenta Ist. ital. Idrobiol., 32: 69-81.

Håvind, 1998. Intercomparaison 9812. pH, conductivity, alkalinity, nitrate + nitrite, chloride, sulfate, calcium, magnesium, sodium, potassium, total aluminium, reactive and non-labile aluminium, dissolved organic carbon, and chemical oxygen demand. NIVA-Report SNO 3939-98, ICP-Waters Report 47/1998. ISBN 82-577-3530-2.

Hurlbert, S.H. 1971. The nonconcept of species diversity: a critique and alternative parameters. Ecology, 52: 577-586.

Jones, R.I. 1994. Mixotrophy in planktonic protists as a spectrum of nutritional strategies. Mar. Microbiol. Food Webs, 8: 87-96.

Manca, M. \& P. Comoli. 1999. Studies on zooplankton of Lago Paione Superiore. In: Straškrabová, V., C. Callieri \& $\mathrm{J}$ Fott (Eds), Pelagic food web in mountain lakes. MOuntain LAkes Research Program. J. Limnol., 58(2): 131-135.

Mosello, R., M. Bianchi, H. Geiss, A. Marchetto, L. Morselli, G.A. Taratari, G. Serrini, G. Serrini Lanza \& H. Muntau. 1996. Aquacon-MedBas Subproject $N^{\circ} 6$. Acid rain analysis. Intercomparison 1/95. Environment Institute, JRC Report, Commission of the European Communities, Ispra, Rep. EUR 16425 EN: 50pp.

NIVA (Norwegian Institute for Water Research). 1996. Measuring and modelling the dynamic response of remote mountain lake ecosystems to environmental change: A programme of Mountain Lake Research. MOLAR Project manual. Wathne B. (Ed.). NIVA-Rep. 3532-96. ISBN 82577-3078-5.

Patrick, S., R.W. Battarbee, B. Wathne \& R. Psenner. 1998: Measuring and modelling the dynamic response of remote mountain lake ecosystems to environmental change: an introduction to the MOLAR project. In: Kovar, K., U. Tappeiner, N.E. Peters, R.G. Craig (Eds), Hydrology, water resources and ecology in headwaters. Proceedings of the HeadWater'98 conference, Merano. International Association of Hydrological Sciences Publ. No. 248, IAHS Press, Wallingford: 403-410.

Pfister, P. \& R. Psenner. 1988. Phytoplankton in Tiroler Hochgebirgseen. In: Psenner, R., U. Nickus \& F. Zapf (Eds), Versauerung von Hochgebirgseen in Kristallinen Einzugsgebieten Tirols und Kärtens. Bundesministerium für Land- und Forstwirtschaft, Wien: 173-208.

Psenner, R., A. Brugger, J. Franzoi, W. Honsig-Erlenburg, W. Müller, U. Nickus \& F. Zapf. 1988. Chemismus der Seenversauerung und Auswirkungen auf das Trinkwasser. In: Psenner, R., U. Nickus \& F. Zapf (Eds), Versauerung von Hochgebirgseen in Kristallinen Einzugsgebieten Tirols und Kärtens. Bundesministerium für Land- und Forstwirtschaft, Wien: 1-146.

The MOLAR Water Chemistry Group. 1999. The MOLAR Project: atmospheric deposition and lake water chemistry. In: Straškrabová, V., C. Callieri \& J Fott (Eds), Pelagic 
food web in mountain lakes. MOuntain LAkes Research Program. J. Limnol., 58(2): 88-106.

Rask, M., P. J. Vuorinen, J. Taitaniemi, M. Vuorinen, A. Lappalainen \& S. Peuranen. 1992. Whitefish stocking in acidified lakes: ecological and physiological response. Hydrobiologia, 243/244: 277-282.

Schneider, U. 1981. Phytoplankton und Primärproduktion in einigen Hochgebirgseen des Kantons Tessins. Dissertation University of Bern: $153 \mathrm{pp}$.

Stokes, P.M. 1986. Ecological effects of acidification on primary producers in aquatic ecosystems. Wat. Air Soil Pollut., 30: 421-438.

Straškrabová, V., C. Callieri, P. Carrillo, L. Cruz-Pizarro, J. Fott, P. Hartman, M. Macek, J.M. Medina-Sánchez, J. Nedoma \& K. Šimek. 1999. Investigations on pelagic food webs in mountain lakes - aims and methods. In: Straškrabová, V., C. Callieri \& J Fott (Eds), Pelagic food web in mountain lakes. MOuntain LAkes Research Program. J. Limnol., 58(2): 77-87.

Stumm, W. \& J. Morgan. 1981. Aquatic Chemistry. $2^{\text {n }}$ d ed., Wiley Interscience, New York.

Thaler, B., D. Tait \& G. Bendetta. 1991. Effects of acidification on alpine lakes in the Province of Bolzano (South Tyrol, Italy). Final Report, Step Programme ALPE 1: 72 pp.

The MOLAR Water Chemistry Group. 1999. The MOLAR Project: atmospheric deposition and lake water chemistry. In: Straškrabová, V., C. Callieri \& J Fott (Eds), Pelagic food web in mountain lakes. MOuntain LAkes Research Program. J. Limnol., 58(2): 88-106.

Washington, H.G. 1984. Diversity, biotic and similarity indices. Wat. Res., 18: 653-694.

Winkler, L.W. 1888. The determination of dissolved oxygen in water. Berlin. Deut. Chem. Ges., 21: 2843. 